Second, they undertake the task in the spirit of generous coöperation, each appreciating the peculiarities of all the rest, and magnanimously striving to utilize, rather than oppose, the diversities of temperament, taste and opinion which inevitably exist among men.

Third, they enter on the labor with a genuine love of truth. The facts of medicine must be clearly observed, the very fabric, the parenchyma, of the mind, must come in contact at every point, that an accurate impression may be obtained; even as the sculptor, in making a cast, takes pains that his clay shall touch every part of the surface, that the work may be true to life. This observation of facts is the basis of all our knowledge; the foundation thus laid we advance by the application of reason to them. In determining questions of science, the mind must be divested of all prejudice, must not be tied to any exclusive dogmas, nor be determined to swear in the words of any particular master. "The love of truth and fairness in searching for it" are both essential to good progress. We should approach our study with the purpose of a judge, not of an advocate.

One result of such work is a growing humility. The mind is observing the work of the Almighty and seeking to get an understanding of IIis infinite ways. It is only the very young student who can boast of his knowledge, and 'spread the gay feathers of conceit and self-satisfaction.

In the spirit of such considerations, we now dedicate these school-rooms to the study of trie medical science.

After the address, speeches were made by the Rev. Edw. Y. Hincks, of the State Street Church; the Hon. Wm. Thomas, Jr., Speaker of the House of Representatives; the Hon. Israel Washburn, Jr., Collector of the Port; and Dr. Alfred Mitchell, Professor of Obstetrics and Diseases of Children in the Medical School of Maine; representing, respectively, theology, law, commerce and medicine. The speakers were all very happy in their remarks, which were received with great favor by the audience. Finally, the assembly, by invitation of the teachers, sat down to an elegant and bountiful supper at the Falmouth Hotel, where further remarks were made by Mr. A. A. Strout, Hon. W. I. Putnam and others.

The summer term commenced the next day, a goodly number of students being in attendance. Systematic daily recitations are held, familiar lectures and demonstrations regularly given, ample clinical advantages afforded and abundant facilities given for the study of practical anatomy. At present, there are twelve instructors:-Drs. Dana, T. A. Foster, Tewksbury, Weeks, Greene, Hunt, Gerrish, French, Gordon, Small, B. B. Foster, and Bray; and, if one may judge from the manner in which a beginning has been made, their anticipations of a successful course will be more than realized.

GAMMA.

\title{
OBbituary.
}

\section{The late George Derby, M.D.}

Messes. Editors, - At a mecting of the Faculty, on the 22d inst., the

following was adopted:-

"IResolved, That the Medical Faculty of Harvard University have learned with the deepest regret of the death of their late associate, Dr. George Derby.

"Ifis talents, zeal and untiring industry made him preëminent in the department over which he presided, and render the loss to the profession and the community almost irreparable, while his high moral character, courtesy and genial manners greatly endeared him to us."

It was also voted that a copy of the above be sent to the MEdicaL JourNAL for publication.

Very respectfully yours,

C. Elurs, Dean. 